\title{
Bone Morphogenetic Protein 10
}

National Cancer Institute

\section{Source}

National Cancer Institute. Bone Morphogenetic Protein 10. NCI Thesaurus. Code C21346.

Bone morphogenetic protein 10 (424 aa, $\sim 48 \mathrm{kDa}$ ) is encoded by the human BMP10 gene. This protein plays a role in both signal transduction and cardiac muscle cell proliferation. 